\title{
Seasonal variability of methane in the rivers and lagoons of Ivory Coast (West Africa)
}

\author{
Y. J. M. Koné • G. Abril • B. Delille • A. V. Borges
}

Received: 3 December 2008/ Accepted: 20 December 2009/Published online: 5 February 2010

(C) Springer Science+Business Media B.V. 2010

\begin{abstract}
We report a data-set of dissolved methane $\left(\mathrm{CH}_{4}\right)$ in three rivers (Comoé, Bia and Tanoé) and five lagoons (Grand-Lahou, Ebrié, Potou, Aby and Tendo) of Ivory Coast (West Africa), during the four main climatic seasons (high dry season, high rainy season, low dry season and low rainy season). The surface waters of the three rivers were over-saturated in $\mathrm{CH}_{4}$ with respect to atmospheric equilibrium (2221-38719\%), and the seasonal variability of $\mathrm{CH}_{4}$ seemed to be largely controlled by dilution during the flooding period. The strong correlation of $\mathrm{CH}_{4}$ concentrations with the partial pressure of $\mathrm{CO}_{2}\left(\mathrm{pCO}_{2}\right)$ and dissolved silicate (DSi) confirm the dominance of a continental sources (from soils) for both $\mathrm{CO}_{2}$ and $\mathrm{CH}_{4}$ in these rivers. Diffusive air-water $\mathrm{CH}_{4}$ fluxes ranged
\end{abstract}

Y. J. M. Koné · B. Delille · A. V. Borges $(\square)$ Unité d'Océanographie Chimique, Institut de Physique (B5), Université de Liège, 4000 Liege, Belgium e-mail: alberto.borges@ulg.ac.be

\section{Y. J. M. Koné}

Laboratoire d'Environnement et de Biologie Aquatique, Université d'Abobo-Adjamé, 02 BP. 801, Abidjan 02, Ivory Coast

\section{Y. J. M. Koné}

Centre de Recherches Océanologiques, 29 Rue de pêcheurs, BP.V 18, Abidjan, Ivory Coast

G. Abril

Laboratoire EPOC, Environnements et Paléoenvironnements OCéaniques, Université de Bordeaux 1, Avenue des Facultés, 33405 Talence, France between 25 and $1187 \mu \mathrm{mol} \mathrm{m}{ }^{-2}$ day $^{-1}$, and annual integrated values were $288 \pm 107,155 \pm 38$, and $241 \pm 91 \mu \mathrm{mol} \mathrm{m}^{-2}$ day $^{-1}$ in the Comoé, Bia and Tanoé rivers, respectively. In the five lagoons, surface waters were also over-saturated in $\mathrm{CH}_{4}$ (ranging from 1496 to $51843 \%$ ). Diffusive air-water $\mathrm{CH}_{4}$ fluxes ranged between 20 and $2403 \mu \mathrm{mol} \mathrm{m}{ }^{-2} \mathrm{day}^{-1}$, and annual integrated values were $78 \pm 34,338 \pm 217$, $227 \pm 79, \quad 330 \pm 153$ and $326 \pm 181 \mu \mathrm{mol} \mathrm{m}{ }^{-2}$ day $^{-1}$ in the Grand-Lahou, Ebrié, Potou, Aby and Tendo lagoons, respectively. The largest $\mathrm{CH}_{4}$ oversaturations were observed in the Tendo and Aby lagoons that are permanently stratified systems (unlike the other three lagoons), leading to anoxic bottom waters favorable for a large $\mathrm{CH}_{4}$ production. In addition, these two stratified lagoons showed low $\mathrm{pCO}_{2}$ values due to high primary production, which suggests an efficient transfer of organic matter across the pycnocline. As a result, the stratified Tendo and Aby lagoons were respectively, a low source of $\mathrm{CO}_{2}$ to the atmosphere and a sink of atmospheric $\mathrm{CO}_{2}$ while the other three well-mixed lagoons were strong sources of $\mathrm{CO}_{2}$ to the atmosphere but less oversaturated in $\mathrm{CH}_{4}$.

Keywords Methane - Lagoons - Rivers · Ivory Coast
Abbreviations
$\% \mathrm{CH}_{4} \quad$ Percent of $\mathrm{CH}_{4}$ saturation
$a \quad$ Coefficient of linear regression 


$\begin{array}{ll}\mathrm{DSi} & \text { Dissolved silica } \\ \mathrm{FCH}_{4} & \text { Diffusive air-water } \mathrm{CH}_{4} \text { flux } \\ \mathrm{HDS} & \text { High dry season } \\ \mathrm{HRS} & \text { High rainy season } \\ k & \text { Gas transfer velocity } \\ k_{600} & \text { Gas transfer velocity normalized to a } \\ & \text { Schmidt number of } 600 \\ \text { Lat } & \text { Latitude } \\ \mathrm{LDS} & \text { Low dry season } \\ \text { Long } & \text { Longitude } \\ \mathrm{LRS} & \text { Low rainy season } \\ n & \text { number of measurements } \\ \mathrm{NCEP} & \text { National Centers for } \\ & \text { Prediction } \\ \mathrm{pCO}_{2} & \text { Partial pressure of } \mathrm{CO}_{2} \\ \mathrm{Sc}_{\mathrm{TgCH}} & \begin{array}{l}\text { Schmidt number of } \mathrm{CH}_{4} \\ \text { Teragrams of } \mathrm{CH}\end{array} \\ u & \text { Wind speed } \\ \Delta\left[\mathrm{CH}_{4}\right] & \text { Air-water gradient of } \mathrm{CH}_{4} \\ \Delta \mathrm{pCO}_{2} & \text { Air-water gradient of } \mathrm{pCO}_{2}\end{array}$

\section{Introduction}

Methane $\left(\mathrm{CH}_{4}\right)$ is an atmospheric trace gas that contributes to $\sim 18 \%$ of global mean radiative forcings of long-lived greenhouse gases (comprising carbon dioxide $\left(\mathrm{CO}_{2}\right), \mathrm{CH}_{4}$, nitrous oxide and halocarbons) (Forster et al. 2007). The $\mathrm{CH}_{4}$ atmospheric concentration has steadily increased since the industrial revolution $(\sim 0.7 \mathrm{ppm})$ and stabilized at $\sim 1.8 \mathrm{ppm}$ from 1999 to 2005 (Forster et al. 2007). An increase in the atmospheric growth of $\mathrm{CH}_{4}$ during years 2006 and 2007 has been recently reported (Rigby et al. 2008).

Among the 500-580 $\mathrm{TgCH}_{4}$ year $^{-1}$ emitted from the Earth surface to the atmosphere during the last three decades, nearly one half originated from wetlands, in majority from natural wetlands (145$230 \mathrm{TgCH}_{4}$ year ${ }^{-1}$ ), but also from artificial wetlands like rice paddies (30-110 $\mathrm{TgCH}_{4}$ year $^{-1}$ ), and hydroelectric reservoirs (70 $\mathrm{TgCH}_{4}$ year $^{-1}$ ) (Cicerone and Oremland 1988; St Louis et al. 2000; Wuebbles and Hayhoe 2002; Mikaloff Fletcher et al. 2004; Denman et al. 2007; Khalil et al. 2007). Recently, lakes have also been identified as a potentially significant additional source of $\mathrm{CH}_{4} \quad\left(8-48 \mathrm{TgCH}_{4}\right.$ year $^{-1}$,
Bastviken et al. 2004). The open ocean is a low source of $\mathrm{CH}_{4}$ estimated at $4-15 \mathrm{TgCH}_{4}$ year $^{-1}$ (Houweling et al. 2000; Wuebbles and Hayhoe 2002). In contrast to the open ocean, the coastal ocean could significantly contribute to $\mathrm{CH}_{4}$ sources. Indeed, at European scale alone, Bange (2006) evaluated the source of $\mathrm{CH}_{4}$ from coastal waters to $0.75 \mathrm{TgCH}_{4}$ year $^{-1}$, among which $0.28 \mathrm{TgCH}_{4}$ year $^{-1}$ from continental shelves and $0.47 \mathrm{TgCH}_{4}$ year $^{-1}$ from estuarine environments. This coastal European source represents between 5 and $19 \%$ of the $\mathrm{CH}_{4}$ source from the global open ocean. The global source of $\mathrm{CH}_{4}$ from coastal environments could be severely under-estimated due to lack of data to adequately quantify estuarine $\mathrm{CH}_{4}$ emissions and geological sources (Bange 2006).

Among coastal environments, estuaries and lagoons are characterized by much higher $\mathrm{CH}_{4}$ over-saturations with respect to atmospheric equilibrium $(3643 \pm 2814 \%$ at European scale, Bange 2006) compared to continental shelves (224 \pm $142 \%$ at European scale, Bange 2006). The $\mathrm{CH}_{4}$ oversaturation in estuarine waters is the result of a complex combination of sources, sinks and transport. In estuarine channels, net $\mathrm{CH}_{4}$ inputs from the sediments to the water column and $\mathrm{CH}_{4}$ production in the water column are generally low because oxic and suboxic respiration dominate (Abril and Borges 2004). Consequently, $\mathrm{CH}_{4}$ in estuarine waters originates from two major sources: (1) rivers, which receive $\mathrm{CH}_{4}$ from soils, groundwater, wetlands and floodplains on the watershed (De Angelis and Lilley 1987; Richey et al. 1988) and (2) tidal wetlands and mud flats, which are generally vegetated and enriched in organic matter to support methanogenesis (Bartlett et al. 1987; Chanton et al. 1989; Kelley et al. 1995; Middelburg et al. 2002; Abril and Borges 2004). Majors sinks of $\mathrm{CH}_{4}$ in estuarine channels are the export to the adjacent coastal zone that dominates in the case of estuaries with a high freshwater discharge and a short residence time (Scranton and McShane 1991; Middelburg et al. 2002), the emission to the atmosphere and the bacterial oxidation in the water column and sediment. The emission of $\mathrm{CH}_{4}$ to the atmosphere usually dominates bacterial oxidation by a factor of 1-20 (De Angelis and Scranton 1993; Lilley et al. 1996; Abril and Iversen 2002; Abril and Borges 2004). In addition, methanotrophic activity in 
estuaries is strongly inhibited by salinity (Scranton and McShane 1991; De Angelis and Scranton 1993), but is enhanced by high turbidity (Abril et al. 2007). Hence, $\mathrm{CH}_{4}$ oxidation is generally confined to the upper reaches of estuaries, where salinity is low and turbidity is high, and where $\mathrm{CH}_{4}$ concentrations are also often highest (Middelburg et al. 2002; Abril et al. 2007).

Lagoons are among the most common near-shore coastal environments occupying $13 \%$ of the World's coastline (Barnes 1980). At the interface between terrestrial and marine environments, lagoons are subject to both continental and marine influences (Castel et al. 1996). The continental inputs into lagoons are mainly from rivers, rain and ground water. This leads to the input of large amounts of particulate material in the form of clay particles and organic detritus but also of dissolved organic carbon and nutrients of natural origin or arising from human activity in the vicinity of the lagoons (fertilizers, domestic and industrial effluents, ...). Most of organic carbon inputs are deposited in the lagoons (Castel et al. 1996) where they fuel intense mineralization (Sorokin et al. 1996) leading to the efflux of $\mathrm{CO}_{2}$ to the atmosphere (Koné et al. 2009). A few studies have addressed the $\mathrm{CH}_{4}$ efflux to the atmosphere from shallow or/and intertidal lagoon sediments (Purvaya and Ramesh 2000; Verma et al. 2002; Hirota et al. 2007), but to our best knowledge, no studies have previously addressed the dynamics of $\mathrm{CH}_{4}$ in surface waters of lagoons, and related diffusive air-water $\mathrm{CH}_{4}$ fluxes.

In the present work, we report a dataset of $\mathrm{CH}_{4}$ obtained in five equatorial lagoons (Grand-Lahou, Ebrié, Potou, Aby and Tendo) in Ivory Coast (West Africa) and three rivers (Comoé, Bia and Tanoé) flowing into these lagoons (Fig. 1), during the four characteristic seasons (Fig. 2). The three studied rivers are the most important in Ivory Coast in terms of freshwater discharge excepted for the Bandama river (Table 1). The five studied lagoons differ by a wide range of riparian population density, of freshwater inputs (Table 1), and of physical settings (permanent or seasonal or no stratification). Hence, these lagoons provide a large spectrum of biogeochemical settings to investigate $\mathrm{CH}_{4}$ dynamics, and are representative of most of the kinds of lagoons encountered in West Africa, and at tropical latitudes.

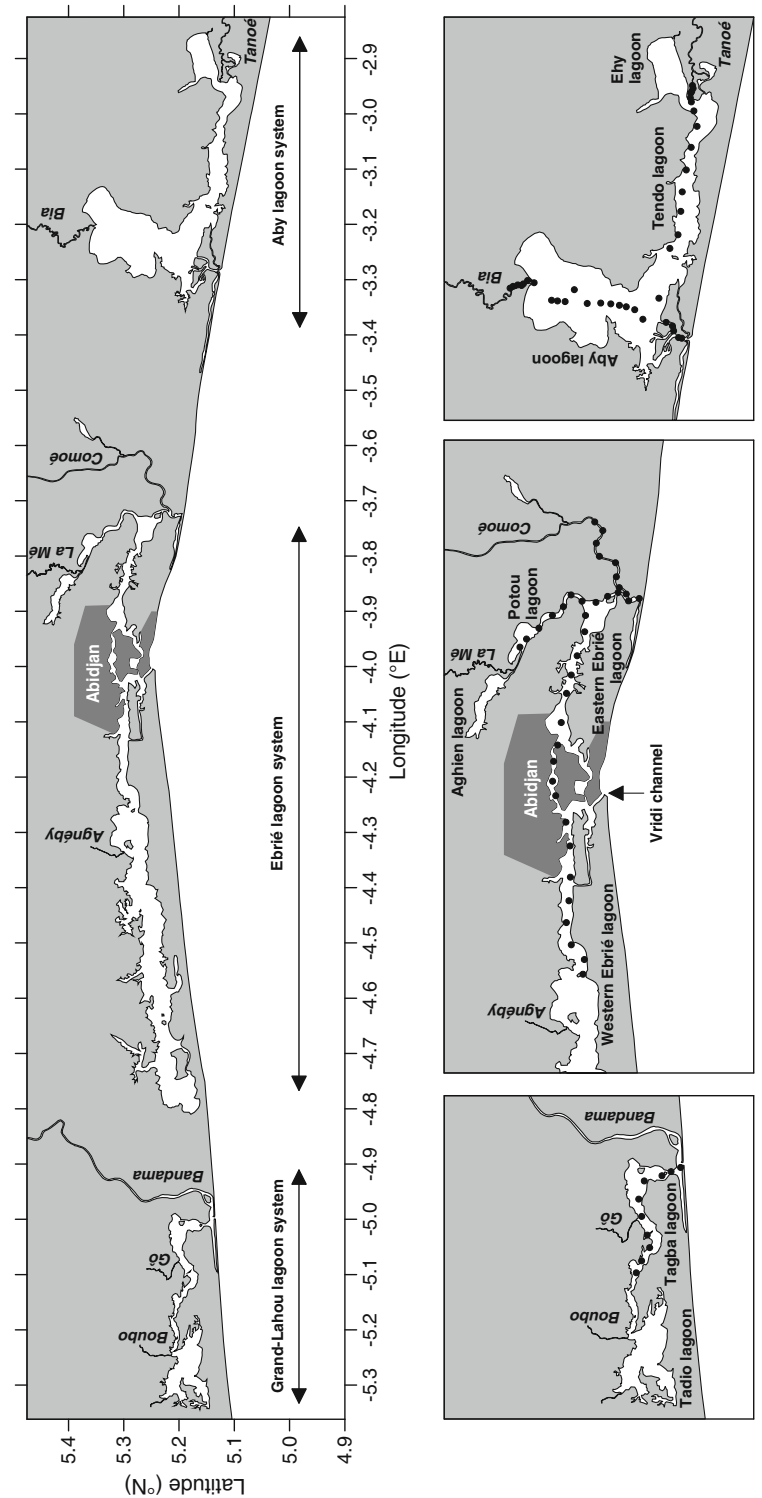

Fig. 1 Map showing the location of lagoons and rivers in Ivory Coast, and the sampling stations (lower panels)

\section{Materials and methods}

Description of study area

The climate in Ivory Coast is close to equatorial, with an annual rainfall ranging from 1500 to $1800 \mathrm{~mm}$, characterized by two rainy seasons and two dry seasons (Durand and Skubich 1982). The high dry season extends from January to March, the high rainy season from early April to late July, the low dry 

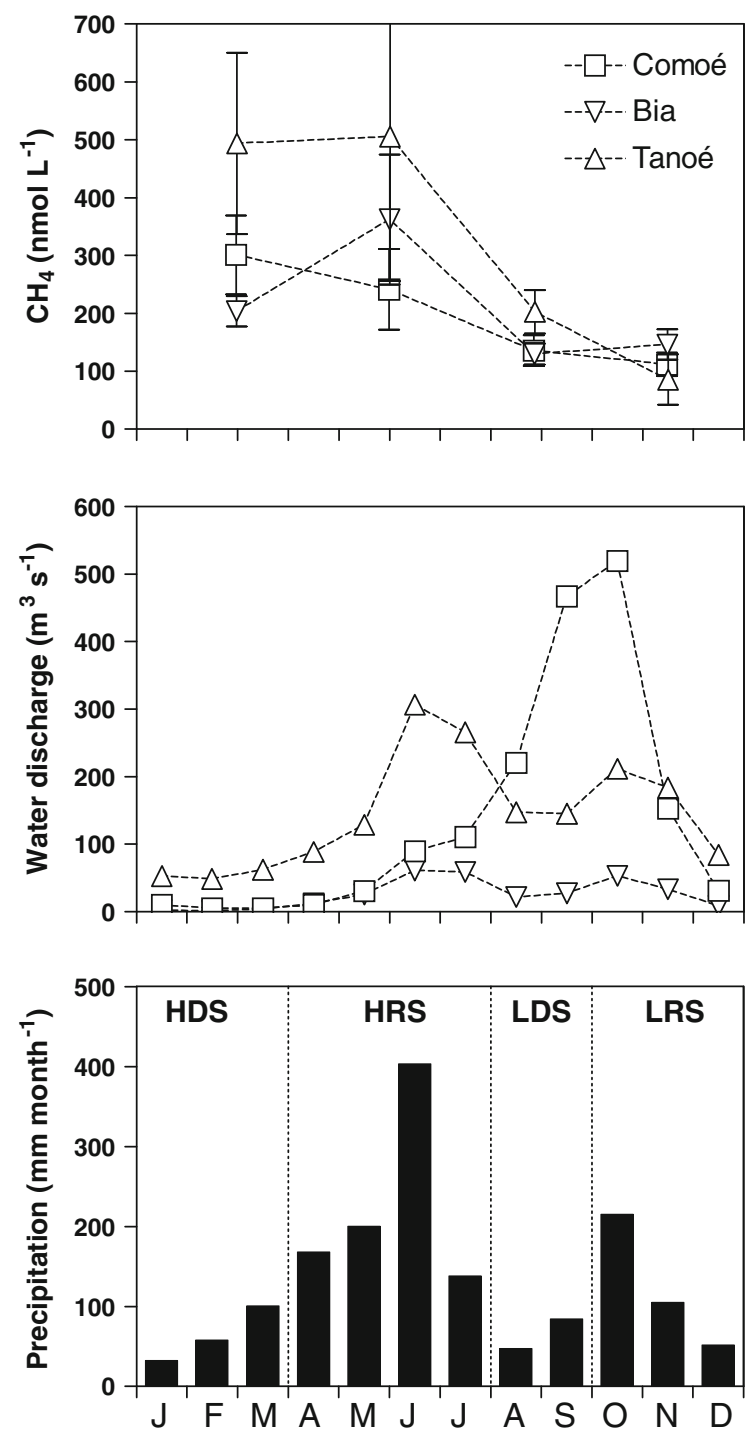

Fig. 2 Seasonal variations of $\mathrm{CH}_{4}$ concentration $\left(\mathrm{nmol} 1^{-1}\right)$ in the Bia $(n=8)$, the Tanoé $(n=8)$ and the Comoé $(n=8)$ rivers, average monthly freshwater discharge $\left(\mathrm{m}^{3} \mathrm{~s}^{-1}\right)$ and average monthly precipitation ( $\mathrm{mm}$ month ${ }^{-1}$ ), during the high dry season (HDS, March), the high rainy season (HRS, June), the low dry season (LDS, September) and the low rainy season (LRS, December). Error bars correspond to standard deviation on the mean

season from August to September, and the low rainy season from October to December (Fig. 2).

The rivers in Ivory Coast have two different hydrological regimes (Jallow et al. 1999). The Tanoé, the Bia, the La Mé and the Agnéby rivers have an equatorial transition regime with two flooding periods in June-July and October-November. The Comoé and Bandama rivers have a mixed regime with only one flooding period in September-October. The lithology of the drainage basin of the three rivers is different: in the Comoé it is composed of $63 \%$ plutonic acids, $26 \%$ of Precambrian basement and $11 \%$ consolidated siliciclastic rocks; in the Bia it is composed of $67 \%$ of Precambrian basement, $17 \%$ plutonic acids and $16 \%$ semi- to unconsolidated sedimentary; in the Tanoé it is exclusively composed of Precambrian basement (Dürr et al. 2005).

Lagoons are the most prominent coastal ecosystems of Ivory Coast (Fig. 1) covering an area of $1200 \mathrm{~km}^{2}$, which corresponds to $\sim 25 \%$ the surface area of lagoons in West Africa (Binet et al. 1995). They are gathered in three systems (Grand-Lahou, Ebrié and Aby) and stretch along some $300 \mathrm{~km}$ of the coastline. The Grand-Lahou lagoon system is the smallest of the Ivory Coast lagoon systems $\left(190 \mathrm{~km}^{2}\right)$, is divided into two lagoons (Tagba and Tadio), and receives freshwater from the Bandama river, and from the smaller Gô and Boubo rivers. The Ebrié lagoon system is the largest lagoon in West Africa $\left(566 \mathrm{~km}^{2}\right)$, is divided into three lagoons (Potou, Aghien and Ebrié), and receives freshwater from the Comoé, Agnéby and La Mé rivers. The Aby lagoon system (surface $424 \mathrm{~km}^{2}$ ) consists of the main Aby lagoon (hereafter Aby lagoon), the Tendo lagoon and the Ehy lagoon, and receives freshwater from the Bia and Tanoé rivers. Inter-tidal areas in these lagoons are occupied by mud-flats and mangroves and correspond to 45,37 and $24 \%$ of the open water surface area in the Aby, Ebrié and Grand-Lahou lagoon systems, respectively (Hughes and Hughes 1992). The main physical characteristics of the Ivory Coast lagoons and rivers are given in Table 1.

The Grand-Lahou lagoon system and the Ebrié lagoon system fall under the ecotype of "restricted lagoons" while the Aby lagoon system falls under the ecotype of "chocked lagoons" based on the classification of Kjerfve (1985). Chocked lagoons are connected to the sea by a very shallow channel hence there is a low propagation of marine tidal and wave energy, unlike restricted lagoons that are connected to the sea by deeper channels. This strongly modulates the physical settings of the Ivory Coast lagoons, as the Aby lagoon system is permanently stratified by a strong vertical salinity gradient (Chantraine 1980) while the Grand-Lahou and Ebrié lagoon systems are well-mixed in shallow areas and seasonally stratified 
Table 1 Main physical characteristics of the lagoons and rivers flowing into these lagoons in Ivory Coast, based on Chantraine (1980), Durand and Chantraine (1982), and Durand and Skubich (1982)

\begin{tabular}{|c|c|c|c|c|c|c|c|c|}
\hline Lagoons & $\begin{array}{l}\text { Area } \\
\left(\mathrm{km}^{2}\right)\end{array}$ & $\begin{array}{l}\text { Volume } \\
\left(\mathrm{km}^{3}\right)\end{array}$ & $\begin{array}{l}\text { Mean } \\
\text { depth (m) }\end{array}$ & $\begin{array}{l}\text { Surface } \\
\text { salinity }\end{array}$ & Rivers & $\begin{array}{l}\text { Total } \\
\text { length }(\mathrm{km})\end{array}$ & $\begin{array}{l}\text { Drainage } \\
\text { area }\left(\mathrm{km}^{2}\right)\end{array}$ & $\begin{array}{l}\text { Mean water } \\
\text { discharge }\left(\mathrm{m}^{3} \mathrm{~s}^{-1}\right)\end{array}$ \\
\hline Tendo & 74 & 0.2 & 2.7 & $0-8$ & Tanoé & 625 & 16000 & 132 \\
\hline Aby & 305 & 1.3 & 4.2 & $1-8$ & Bia & 290 & 9650 & 59 \\
\hline \multirow[t]{2}{*}{ Ebrié } & 524 & 2.6 & 4.8 & $0-35$ & Comoé & 1160 & 78000 & 224 \\
\hline & & & & & Agnéby ${ }^{a}$ & 200 & 8900 & 27 \\
\hline Potou & 22 & 0.03 & 2.7 & $0-6$ & $\mathrm{La} \mathrm{Mé}^{\mathrm{a}}$ & 140 & 4300 & 47 \\
\hline Grand-Lahou & 190 & 0.5 & 2.0 & $0-26$ & Bandama $^{\mathrm{a}}$ & 1050 & 97000 & 298 \\
\hline
\end{tabular}

${ }^{a}$ Not sampled

in deeper areas. Tidal amplitude in the Ebrié lagoon system is $<1 \mathrm{~m}$ (Brenon et al. 2004), and should be similar in the Grand-Lahou lagoon system but lower in the Aby lagoon system (data unavailable for the latter two lagoon systems).

The density of the riparian population is variable ranging from 3.5 inhabitants $\mathrm{km}^{-2}$ around the Aby lagoon system to $\sim 100$ inhabitants $\mathrm{km}^{-2}$ around the Ebrié lagoon system (Jallow et al. 1999). Hence, the Grand-Lahou and Aby lagoon systems are relatively pristine, while the Ebrié lagoon system is strongly polluted by domestic and industrial waste water inputs (Kouassi et al. 1995; Adingra and Arfi 1998). The waters around Abidjan are highly eutrophicated leading to frequent oxygen depletion, and massive fish kills and repelling sulphuric smells (Kouassi et al. 1995; Scheren et al. 2004), and have been included in the recent compilation of coastal "dead zones" (Diaz and Rosenberg 2008).

Sampling, analytical techniques and statistics

Four cruises were carried out (08 June to 07 July 2006, 06-22 September 2006, 24 November to 13 December 2006, 08-30 March 2007) to sample five lagoons (Grand-Lahou, Ebrié, Potou, Aby and Tendo) and three rivers (Comoé, Bia and Tanoé). The cruise in June-July is representative of the high rainy season, the cruise in September of the low dry season, the cruise in November-December of the low rainy season, and the cruise in March of the high dry season (Fig. 2). On average for each cruise, 8 samples were obtained in the Comoé river, 8 samples in the Bia river, 8 samples in the Tanoé river, 10 samples in the Grand-Lahou lagoon,
23 samples in the Ebrié lagoon, 6 samples in the Potou lagoon, 16 samples in the Aby lagoon and 8 samples in the Tendo lagoon (Fig. 1).

Sampling was carried out with a 1.71 Niskin bottle in subsurface waters at a depth of $\sim 30 \mathrm{~cm}$ and a vertical profile was carried out in March 2007 in the Aby and Tendo lagoons. Water was sampled in serum bottles of $40 \mathrm{ml}$ taking care to avoid formation of bubbles, poisoned with $\mathrm{HgCl}_{2}$ and sealed. Concentrations of $\mathrm{CH}_{4}$ were determined by gas chromatography with flame ionization detection, after creating a $12 \mathrm{ml}$ headspace with $\mathrm{N}_{2}$, as described by Abril and Iversen (2002). Certified $\mathrm{CH}_{4}: \mathrm{N}_{2}$ mixtures (Air Liquide) of 10 and $500 \mathrm{ppm} \mathrm{CH}_{4}$ were used as standards. At all stations, $\mathrm{CH}_{4}$ samples were obtained in duplicate and the overall reproducibility of $\mathrm{CH}_{4}$ concentration measurements was better than $\pm 5 \%$. Dissolved $\mathrm{CH}_{4}$ concentration was calculated with the solubility coefficient of Yamamoto et al. (1976). Salinity and water temperature were measured in situ using a portable thermosalinometer (WTW Cond340) with a precision of \pm 0.1 and $\pm 0.1^{\circ} \mathrm{C}$, respectively. Wind speed $(u)$ was measured at each sampling station with a hand-held anemometer for a period of about $5 \mathrm{~min}$.

Diffusive air-water fluxes of $\mathrm{CH}_{4}$ were calculated according to:

$\mathrm{FCH}_{4}=k \Delta\left[\mathrm{CH}_{4}\right]$

where $k$ is the gas transfer velocity of $\mathrm{CH}_{4}$ and $\Delta\left[\mathrm{CH}_{4}\right]$ is the air-water gradient of $\mathrm{CH}_{4}$ computed from $\mathrm{CH}_{4}$ concentration in the water and a constant atmospheric $\mathrm{CH}_{4}$ concentration of $1.8 \mathrm{ppm}$.

$k$ was computed from $k$ normalized to a Schmidt number of $600\left(k_{600}\right)$ according to: 
$k=k_{600} \sqrt{\frac{600}{\mathrm{Sc}}}$

where Sc is the Schmidt number of $\mathrm{CH}_{4}$ computed from water temperature with the formulations for salinity 0 and 35 given by Wanninkhof (1992), and to a given salinity assuming that Sc varies linearly with salinity.

$k_{600}$ was computed from $u$ using the "non-dome data" parameterization given by Raymond and Cole (2001):

$k_{600}=1.58 e^{0.3 u}$

This parameterization is based on $14 k_{600}$ data points derived for the mass balance of naturally occurring tracers $\left({ }^{222} \mathrm{Rn}\right.$ and chlorofluorocarbons) and purposeful tracers $\left({ }^{3} \mathrm{He}\right.$ and $\left.\mathrm{SF}_{6}\right)$ gathered from five rivers and estuaries. This parameterization assumes by its formulation that wind speed is the main driver of water turbulence and $k$.

The $u$ values from field measurements at about $2 \mathrm{~m}$ height were referenced to $10 \mathrm{~m}$ height using the formulation given by Johnson (1999). In order to take into account site specific wind sheltering by environmental windbreaks, for each study site a relationship was derived between the daily averages of measured $u$ values and the daily $u$ values from the National Centers for Environmental Prediction (NCEP) reanalysis daily averages surface flux (http://www.cdc. noaa.gov/), averaged at four stations covering the sampled region $\left(-10.63^{\circ} \mathrm{E} 6.67^{\circ} \mathrm{N} ;-8.75^{\circ} \mathrm{E} 6.67^{\circ} \mathrm{N}\right.$; $-10.63^{\circ} \mathrm{E} 4.76^{\circ} \mathrm{N} ;-8.75^{\circ} \mathrm{E} 4.76^{\circ} \mathrm{N}$ ) (Table 2). These relationships are site specific due to variable damping effect of wind speed, related for instance to forest cover in the rivers. The correlation between daily averages of $u$ field measurements and the NCEP daily $u$ values was overall good, and statistical significance of the correlations increased with increasing range of $u$ values and increasing number of data points (Table 2). The coefficient ( $a$ ) of the linear regressions forced through zero was below unit in the narrower and more sheltered rivers (Bia and Tanoé) and was highest in the Ebrié lagoon, the most extensive and less sheltered of the lagoons. Hereafter, $u$ refers to the NCEP values adjusted with the $a$ values given in Table $2 . \mathrm{FCH}_{4}$ was computed with the adjusted daily NCEP $u$ values for a time period of 1 month centred on the date of the middle of each field cruise. Such an approach allows to account for the day-to-day
Table 2 Coefficient ( $a$ ) of the linear regressions forced through zero between daily wind speeds from the NCEP (averaged at four stations covering the sampled region $\left(-10.63^{\circ} \mathrm{E} 6.67^{\circ} \mathrm{N}\right.$; $\left.-8.75^{\circ} \mathrm{E} 6.67^{\circ} \mathrm{N} ;-10.63^{\circ} \mathrm{E} 4.76^{\circ} \mathrm{N} ;-8.75^{\circ} \mathrm{E} 4.76^{\circ} \mathrm{N}\right)$ ) and daily averages of wind speeds measured in field merged from all cruises, number of data points $(n)$ and range of daily averages of wind speeds measured in field in the Comoé, Bia and Tanoé rivers, and the Grand-Lahou, Ebrié, Potou, Aby and Tendo lagoons

\begin{tabular}{lllll}
\hline & $a$ & $n$ & $r^{2}$ & Range $\left(\mathrm{m} \mathrm{s}^{-1}\right)$ \\
\hline Rivers & & & & \\
Comoé & 1.46 & 4 & 0.86 & $0.9-5.1$ \\
Bia & 0.55 & 4 & 0.70 & $1.2-2.0$ \\
Tanoé & 0.59 & 4 & 0.24 & $0.8-1.9$ \\
Lagoons & & & & \\
Grand-Lahou & 1.45 & 4 & 0.27 & $2.4-5.8$ \\
Ebrié & 2.07 & 7 & 0.69 & $1.5-7.5$ \\
Potou & 1.38 & 4 & 0.82 & $1.7-4.4$ \\
Aby & 1.34 & 7 & 0.63 & $1.0-6.7$ \\
Tendo & 1.75 & 4 & 0.34 & $2.1-6.2$ \\
\hline
\end{tabular}

variability of $u$ in each of the study sites, and to provide $\mathrm{FCH}_{4}$ values that are seasonally representative.

Average monthly rainfall was obtained during 2000-2006 at Adiaké station $\left(-3.3^{\circ} \mathrm{E} 5.28^{\circ} \mathrm{N}\right)$ close to Aby lagoon, provided by the Direction Météorologique d'Adiaké. Average monthly freshwater discharge values during 2000-2005 were measured at Bianou and Yakassé stations for the Bia and the Comoé rivers, respectively (data from the Direction de l'Eau d'Abidjan). Average monthly freshwater discharge values in the Tanoé river were only available for 1978, at Alanda station (from the University of New Hampshire Global Runoff Data Centre, available at http://www.grdc.sr.unh.edu/). Hence, freshwater discharge and precipitation data in Fig. 2 are climatological values for indicative purposes only, and preclude us of making a direct comparison with our field data, since freshwater discharge data contemporary to our sampling were not available.

Sample means were compared (across sampling sites in each season and across seasons within each site) statistically using a two tailed unpaired Student $t$ test, using Prism 4.00 (GraphPad). $P$ values are not explicitly mentioned hereafter but "significant(ly)" refers to $P<0.05$, "very significant(ly)" refers to $P<0.01$, "highly significant(ly)" refers to $P<0.001$, and "not significant(ly)" refers to $P>0.05$ at 0.05 level. 


\section{Results and discussion}

Dynamics of $\mathrm{CH}_{4}$ in the three rivers

Figure 2 shows the seasonal variations of $\mathrm{CH}_{4}$ in the Comoé, Bia and Tanoé rivers. Surface waters were always over-saturated in $\mathrm{CH}_{4}$ with respect to equilibrium with the atmosphere, with $\mathrm{CH}_{4}$ concentrations ranging from $48 \mathrm{nmol} \mathrm{l}^{-1}$ (i.e., $2221 \%$ of saturation) to $870 \mathrm{nmol}^{-1}$ (i.e., $38719 \%$ of saturation). These $\mathrm{CH}_{4}$ over-saturations are within the range reported for temperate and tropical rivers ranging between $\sim 260$ and $128420 \%$ (e.g., literature compilations by UpstillGoddard et al. 2000 and by Middelburg et al. 2002). The amplitude of the seasonal variations of $\mathrm{CH}_{4}$ was high, $\sim 190,230$ and $420 \mathrm{nmol} \mathrm{l}^{-1}$ in the Comoé, Bia and Tanoé rivers, respectively. An overall decrease of $\mathrm{CH}_{4}$ concentrations occurred in the three rivers from the low water period to the flooding period, suggesting that dilution due to increased freshwater discharge was a major driver of the seasonal cycle. Similar seasonal patterns with a $\mathrm{CH}_{4}$ maximum during summer (low water period) and a $\mathrm{CH}_{4}$ minimum during winter (flooding period) have been observed in lowland temperate European rivers (Middelburg et al. 2002; Abril et al. 2007). This pattern might be due on the one hand to large dilution and high degassing rates during the flooding period (Hope et al. 2001) and, on the other hand, to limitation of in-stream $\mathrm{CH}_{4}$ production at high discharge (De Angelis and Scranton 1993). In addition, during the flooding period, rivers receive preferentially waters from surface runoff, that are poor in $\mathrm{CH}_{4}$, and contribution of $\mathrm{CH}_{4}$ inputs from ground waters becomes minor. Conversely, during the low water period, deep pathways of ground waters enriched in $\mathrm{CH}_{4}$ dominate, which leads to higher $\mathrm{CH}_{4}$ concentrations in river waters (Jones and Mulholland 1998a, b).

Koné et al. (2009) reported the seasonal pattern of $\mathrm{pCO}_{2}$ and dissolved silicate (DSi) in the same three Ivory Coast rivers, and these authors concluded that $\mathrm{pCO}_{2}$ was mainly derived from drained soil $\mathrm{CO}_{2}$, and that DSi was derived from rock weathering. The seasonal cycles of these two quantities were strongly controlled by dilution during the flooding period. The positive relationship between the seasonal average $\mathrm{CH}_{4}$ concentrations and seasonal average $\mathrm{pCO}_{2}$ and DSi (Fig. 3) suggests that drainage of soil $\mathrm{CH}_{4}$ and dilution during the flooding period are the major
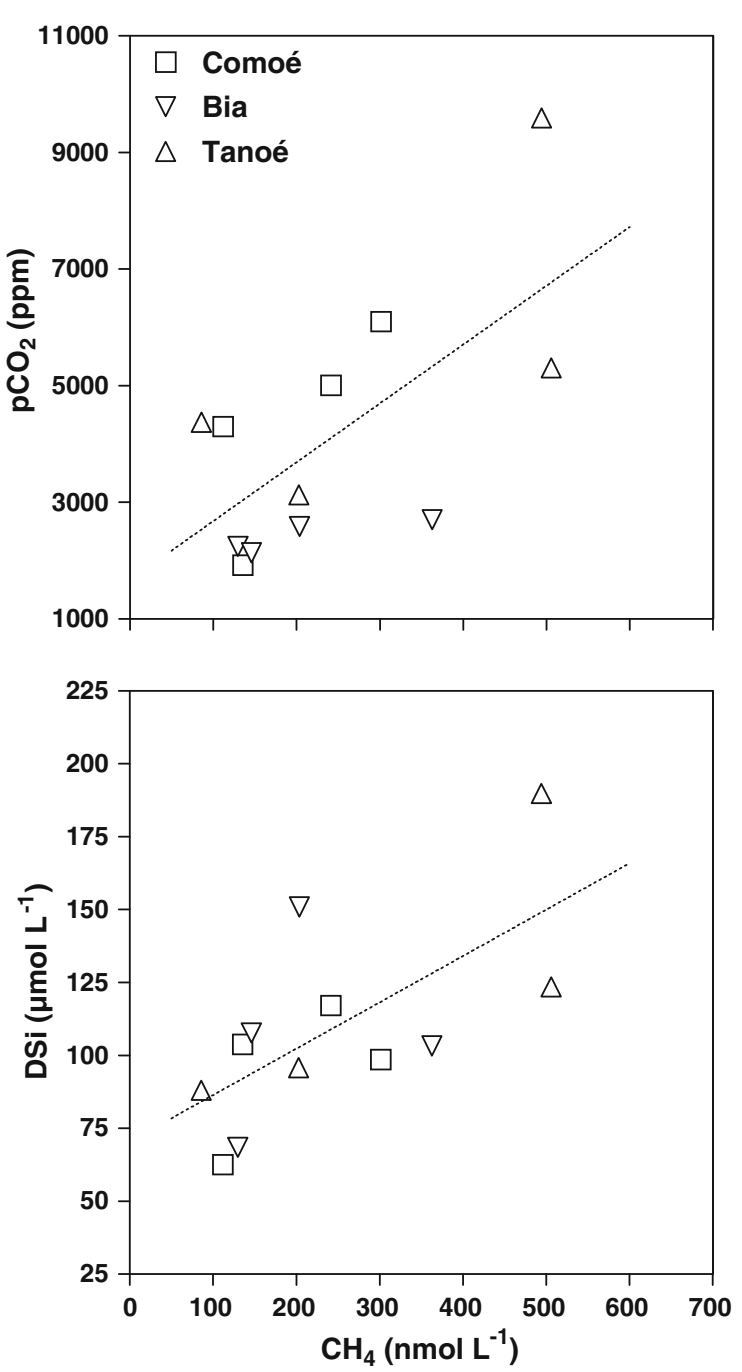

Fig. 3 Comparison of seasonal averages of $\mathrm{CH}_{4}$ concentrations $\left(\mathrm{nmol}{ }^{-1}\right)$ and partial pressure of $\mathrm{CO}_{2}\left(\mathrm{pCO}_{2}\right.$ in $\left.\mathrm{ppm}\right)$ and dissolved silicate (DSi in $\left.\mu \mathrm{mol} 1^{-1}\right)$ in the Bia $(n=8)$, the Tanoé $(n=8)$ and the Comoé $(n=8)$ rivers. The $\mathrm{pCO}_{2}$ and DSi data were obtained at the same locations and same dates as the $\mathrm{CH}_{4}$ data (Koné et al. 2009). Linear regression for $\mathrm{pCO}_{2}$ (dotted line) yields $r^{2}=0.43$ and $P=0.0201$ for the DSi (dotted line) yields $r^{2}=0.44$ and $P=0.0188$

drivers of $\mathrm{CH}_{4}$ in these three rivers, as previously reported in several temperate rivers (e.g., UpstillGoddard et al. 2000; Hope et al. 2001; Middelburg et al. 2002).

Jones and Mulholland (1998a) investigated in detail the spatial variations of riverine $\mathrm{CH}_{4}$ concentrations in several temperate rivers in the U.S.A. along gradients of stream size, elevation and soil organic carbon content. These authors reported a $\mathrm{CH}_{4}$ 
maximum in small headwater streams at highest elevation and organic soil content, that they attributed to large $\mathrm{CH}_{4}$ groundwater inputs from soils. In contrast, in lowland rivers, summer $\mathrm{CH}_{4}$ concentrations increased with river size and moving downstream, due to higher in-stream $\mathrm{CH}_{4}$ production. This spatial trend is also consistent with the seasonal $\mathrm{CH}_{4}$ maximum at low discharge in many temperate rivers (Lilley et al. 1996; Middelburg et al. 2002; Abril et al. 2007). $\mathrm{CH}_{4}$ in rivers originates from the combination of a terrestrial source, dominating at high river discharge when concentrations are lower or similar, and an aquatic source, dominating at low discharge, when concentrations can be much higher (De Angelis and Lilley 1987; Middelburg et al. 2002). As suggested by Middelburg et al. (2002), river size is not the only important factor to explain differences in $\mathrm{CH}_{4}$ concentrations across different rivers. In the Ivory Coast rivers we sampled, during the high dry season (March) and the high rainy season (June), the average $\mathrm{CH}_{4}$ concentrations (Table 3) were significantly to highly significantly higher in the smaller Bia river than in the larger Comoé river, (Table 1), confirming the dominance of a terrestrial $\mathrm{CH}_{4}$ source (from soils).

The average $\mathrm{CH}_{4}$ concentrations in the three studied rivers (Table 3) are quite high compared to other small tropical rivers such as Kaneohe river (Hawaii, $33 \mathrm{nmol} \mathrm{l}^{-1}$, Sansone et al. 1999), Sepik river (Papua New Guinea, 80-130 nmol $1^{-1}$, Wilkinson et al. 1978), or large river mainstems as the Orinoco river (Venezuela, 160-190 nmol ${ }^{-1}$, Smith et al. 2000), the Amazon river (Brazil, 44-62 $\mathrm{nmol} \mathrm{l}^{-1}$, Richey et al. 1988; 150-210 nmol 1 ${ }^{-1}$, Bartlett et al. 1990), and the Yangtze river (China, 112-190 $\mathrm{nmol} \mathrm{1}^{-1}$, Zhang et al. 2004). However, the $\mathrm{CH}_{4}$ concentrations in our three studied rivers are well below the $\mathrm{CH}_{4}$ concentrations in the Amazon floodplains where $\mathrm{CH}_{4}$ concentrations can be as high as $100000 \mathrm{nmol} \mathrm{l}^{-1}$ (Richey et al. 1988; Bartlett et al. 1990) due to strong local $\mathrm{CH}_{4}$ production fuelled by organic carbon inputs from macrophytes and flooded forest. Based on the extent of inundation reported by Hughes and Hughes (1992) we estimate that the surface area of floodplains corresponds between $\sim 5$ and 10 times the surface area of the Comoé river mainstem. This could explain the higher $\mathrm{CH}_{4}$ concentrations in the Ivory Coast rivers than in the small tropical rivers (Kaneohe and Sepik rivers). However, the ratio between the water volume of the mainstem to the lateral inputs of $\mathrm{CH}_{4}$ from the floodplains should also modulate the $\mathrm{CH}_{4}$ content of the mainstem (for an equal lateral flux of $\mathrm{CH}_{4}$ from the floodplains, the increase of $\mathrm{CH}_{4}$ in the mainstem will be higher if the volume of the mainstem is lower). This could explain why $\mathrm{CH}_{4}$ concentrations in the Amazon mainstem are lower than in the Ivory Coast rivers, while the inundated floodplain surface area corresponds to $\sim 34$ times the surface area of the mainstem during high water (Richey et al. 2002).

Dynamics of $\mathrm{CH}_{4}$ in the five lagoons

Figure 4 shows the seasonal and spatial variations of $\mathrm{CH}_{4}$ in surface waters of the five sampled lagoons and associated rivers (data are presented as a function of longitude (Long) for the Grand-Lahou, Ebrié and Tendo lagoons and as a function of latitude (Lat) for the Potou and Aby lagoons). Surface waters were always over-saturated in $\mathrm{CH}_{4}$ with respect to equilibrium with the atmosphere, with $\mathrm{CH}_{4}$ concentrations ranging from $34 \mathrm{nmol}^{-1}$ (i.e., $1496 \%$ of saturation) to $1004 \mathrm{nmol}^{-1}$ (i.e., $51843 \%$ of saturation). These $\mathrm{CH}_{4}$ over-saturations are within the range reported for temperate and tropical estuarine environments ranging between $\sim 70$ and $160000 \%$ (Bange et al. 1994; Upstill-Goddard et al. 2000; Middelburg et al. 2002; Abril and Borges 2004; Bange 2006; Shalini et al. 2006).

The seasonal and spatial variations of $\mathrm{CH}_{4}$ in the surface waters of the lagoons are the result of the balance between transport, outgassing to the atmosphere, and production and oxidation in waters and sediments of the lagoon. A significant decrease in $\mathrm{CH}_{4}$ concentrations at the river-lagoon transition was observed during several seasons: between the Comoé river and the Ebrié lagoon (Long $-3.9^{\circ} \mathrm{E}$ to $-3.6^{\circ} \mathrm{E}$ ) in March, June and September; between the Bia river and the Aby Lagoon (Lat $5.3^{\circ} \mathrm{N}$ to $5.4^{\circ} \mathrm{N}$ ) in June; between the Tanoé river and the Tendo lagoon (Long $-3.0^{\circ} \mathrm{E}$ to $-2.8^{\circ} \mathrm{E}$ ) at all seasons except in December during the low rainy season (Fig. 4). During the low rainy season (December), $\mathrm{CH}_{4}$ concentrations in the Comoé and Bia rivers were not significantly different from those in their respective lagoons (Ebrié and Aby) and the Tanoé river showed low $\mathrm{CH}_{4}$ concentrations due to dilution (Fig. 2). Finally, during the high dry season (March), the $\mathrm{CH}_{4}$ concentrations were significantly higher in 


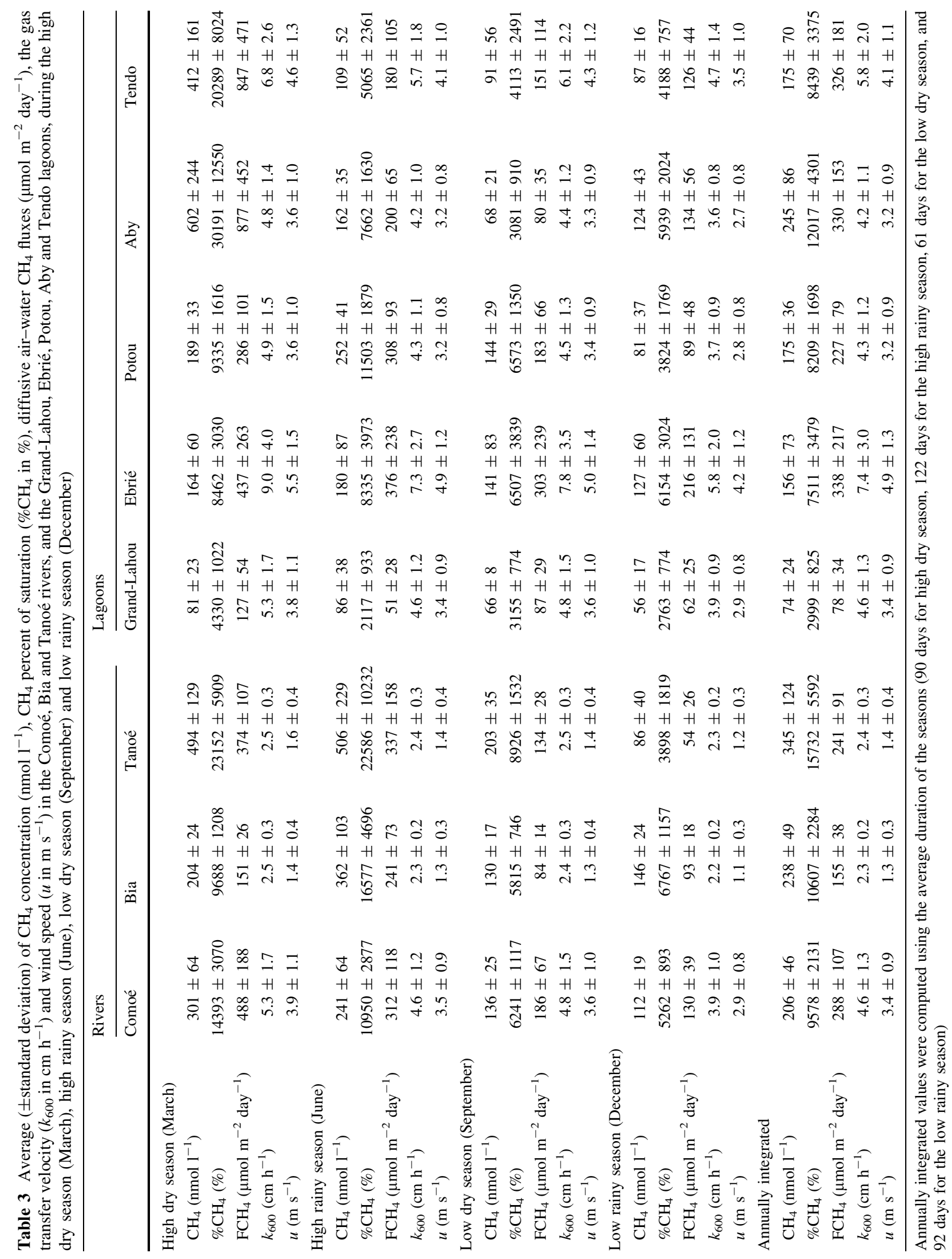


the two stratified lagoons (Aby and Tendo), than in their respective river.

In some cases, the decrease of $\mathrm{CH}_{4}$ between the river-lagoon transition occurred for zero or nearly zero salinity, as also observed at the river-estuary transition (zero salinity region) of several estuaries like for instance the Hudson, the Columbia, the Parker, the Thames, the Gironde and the Randers Fjord (De Angelis and Scranton 1993; Sansone et al. 1999; Middelburg et al. 2002; Abril and Iversen 2002; Abril et al. 2007). This reflects the dominance of $\mathrm{CH}_{4}$ outgassing and/or $\mathrm{CH}_{4}$ oxidation over $\mathrm{CH}_{4}$ production in these areas. The ratio between $\mathrm{CH}_{4}$ oxidation and $\mathrm{CH}_{4}$ outgassing is affected by several environmental conditions such as increasing depth and turbidity that favour $\mathrm{CH}_{4}$ oxidation, increasing salinity that inhibits $\mathrm{CH}_{4}$ oxidation, and increasing wind and tidal currents that enhance $\mathrm{CH}_{4}$ outgassing (De Angelis and Scranton 1993; Abril and Iversen 2002; Abril et al. 2007). In some cases, an intermediate $\mathrm{CH}_{4}$ maximum also occurs at the river-estuary transition where low hydrodynamics might favour local sedimentation of organic material and $\mathrm{CH}_{4}$ production (Upstill-Goddard et al. 2000; Abril et al. 2007). In Ivory Coast, the entrance of the Tanoé river into the Tendo Lagoon and the entrance of the Comoé River into the Ebrié lagoon are the regions of net $\mathrm{CH}_{4}$ loss. Wind speed was always significantly higher in the lagoons than in rivers (Table 3), enhancing the efflux of riverine $\mathrm{CH}_{4}$ to the atmosphere at the entrance of the lagoons. Also, in the central Ebrié lagoon, tidal current speeds can reach $\sim 0.9 \mathrm{~m} \mathrm{~s}^{-1}$, higher than near the mouth of the Comoé river $\sim 0.1 \mathrm{~m} \mathrm{~s}^{-1}$ (Brenon et al. 2004), and thus increasing $k$ (e.g. Zappa et al. 2003; Borges et al. 2004a, b), potentially further enhancing $\mathrm{CH}_{4}$ outgassing. The enhancement of bacterial $\mathrm{CH}_{4}$ oxidation by suspended matter (Abril et al. 2007) is probably limited in the studied river-lagoon transitions, where the concentration of suspended matter never exceeds $20 \mathrm{mg} \mathrm{l}^{-1}$ (Koné et al. 2009).

The $\mathrm{CH}_{4}$ distribution in the Grand-Lahou and Potou lagoons showed low spatial and seasonal variability, with concentrations always lower than $300 \mathrm{nmol}^{-1}$ and typical amplitudes of spatial variations of $\sim 70$ and $110 \mathrm{nmol} \mathrm{l}^{-1}$, respectively (Fig. 4). Such homogeneity in $\mathrm{CH}_{4}$ distributions suggest stable conditions, with low $\mathrm{CH}_{4}$ production and oxidation rates in these two well mixed lagoons.
In the Ebrié Lagoon, whatever the season, average $\mathrm{CH}_{4}$ concentrations in the vicinity of the city of Abidjan were significantly to highly significantly higher than in western Ebrié lagoon and the eastern Ebrié lagoon (Long $<-3.8^{\circ} \mathrm{E}$ ). This $\mathrm{CH}_{4}$ maximum occurred at high salinity during the high dry season (March), at intermediate salinities during the low dry season (September) and the low rainy season (December) and at low salinities during the high rainy season (March) (Fig. 4). Despite strong seasonal salinity variations, no significant seasonal differences were observed in average $\mathrm{CH}_{4}$ concentrations in the vicinity of the city of Abidjan (Fig. 4). This $\mathrm{CH}_{4}$ maximum is most probably related to local production of $\mathrm{CH}_{4}$ fuelled by untreated wastewater inputs from the city of Abidjan ( $\sim 3.8$ million inhabitants).

The highest $\mathrm{CH}_{4}$ concentrations in surface waters were observed in the two permanently stratified Aby and Tendo lagoons. During the low rainy season (December), when $\mathrm{CH}_{4}$ concentrations in the Bia river were lowest due to dilution ("Dynamics of $\mathrm{CH}_{4}$ in the three rivers"), average $\mathrm{CH}_{4}$ concentrations in the Bia river and the Aby lagoon were not significantly different. During the high dry season (March), average $\mathrm{CH}_{4}$ concentrations in the Aby and Tendo lagoons were highly significantly higher than in the Bia and Tanoé rivers, indicating a local production of $\mathrm{CH}_{4}$ in these stratified lagoons. The average $\mathrm{CH}_{4}$ concentrations in the Aby and Tendo lagoons during the high dry season (March) were also very significantly to highly significantly higher than in the three other lagoons and than during the other three seasons in both the Aby and Tendo lagoons. During the high dry season (March), $\mathrm{CH}_{4}$ was positively correlated with salinity (Fig. 5) in surface waters of the Aby $\left(r^{2}=0.66, P=0.0001\right.$, $n=16)$ and the Tendo $\left(r^{2}=0.84, P=0.0013\right.$, $n=8$ ) lagoons, confirming a local production of $\mathrm{CH}_{4}$.

Vertical profiles in the water column of the Aby and Tendo lagoons in March (Fig. 6) reveal very high $\mathrm{CH}_{4}$ concentrations below the pycnocline, where anoxia prevails (Chantraine 1980). Anoxia favours the degradation of organic matter by methanogenesis in the sediments, and leads to the built up of high $\mathrm{CH}_{4}$ concentrations below the pycnocline. Similar vertical $\mathrm{CH}_{4}$ profiles have been reported in several permanently stratified marine systems, and are typical for $\mathrm{CH}_{4}$ production in the bottom layers, vertical transport across the oxycline and intense $\mathrm{CH}_{4}$ oxidation in the surface layers (Ward et al. 1987; Fenchel et al. 

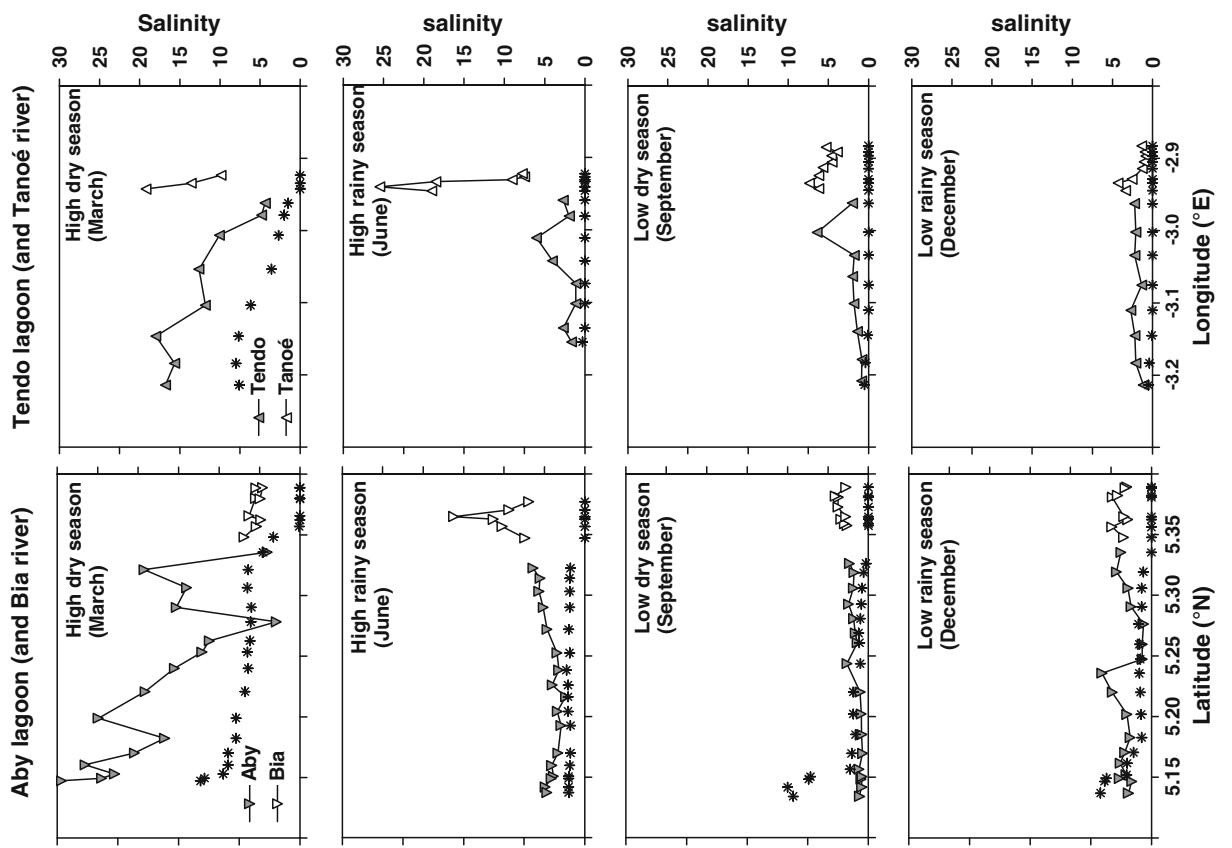

芯
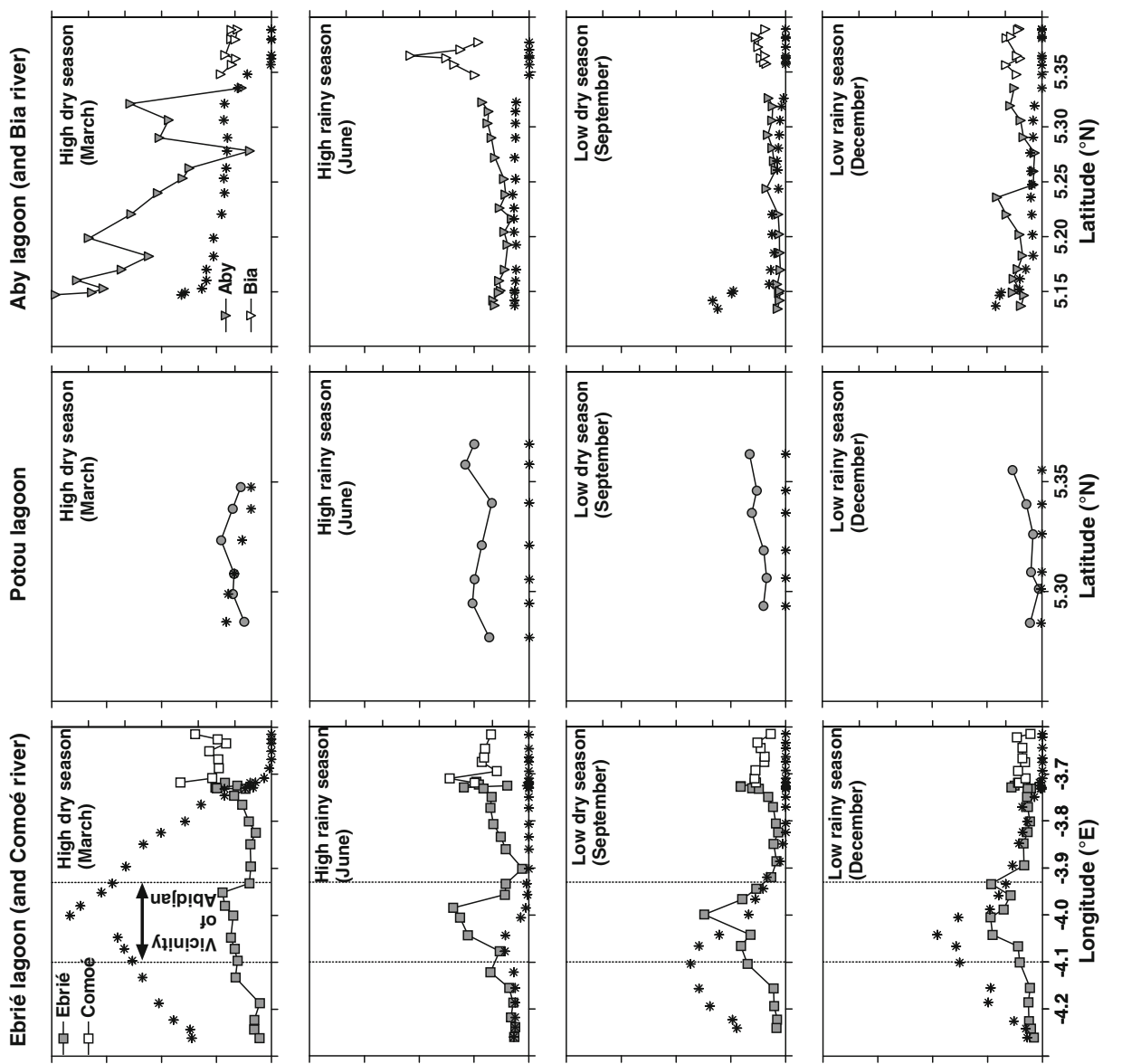

ธี

品 包

융 홀

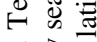

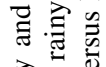

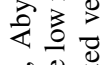

ڤేڤ

璃

I $\frac{\pi}{0}$

हैं है

공ำ

需市命

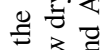

. 응 즈

I $\stackrel{0}{0}$

串导
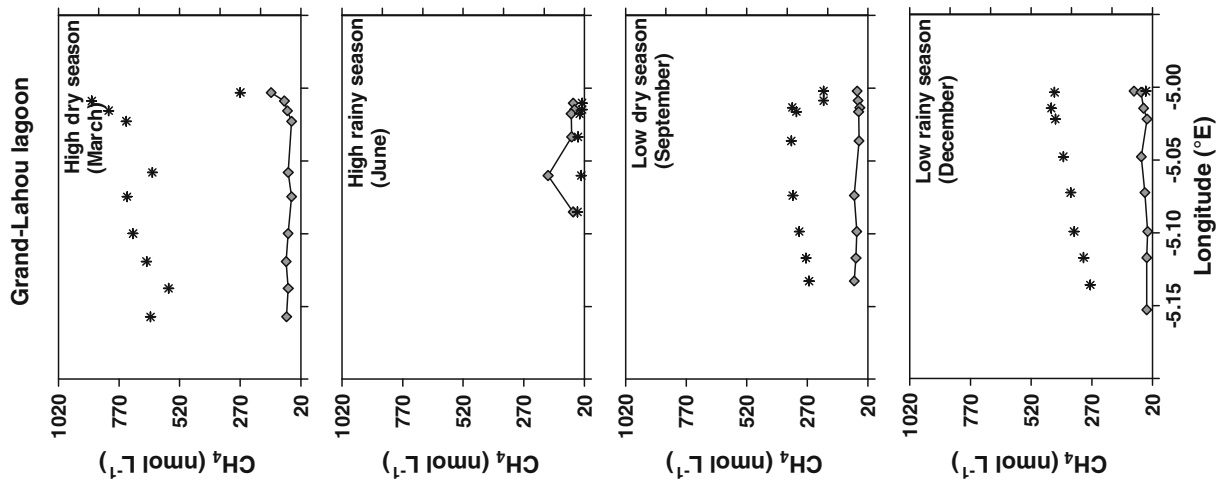

के

ร :

के

ذิ

C.

을

䒕

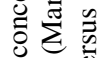

坖泀总

司苛

ปิ

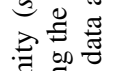

芯芯苛

पे

产芯

窲㞼导

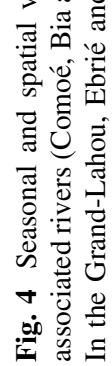

(1.-7 louuu) ${ }^{t} \mathrm{HO}$ 
Fig. 5 Seasonal variations of $\mathrm{CH}_{4}$ concentration (nmol $1^{-1}$ ) as a function of salinity in the Grand-Lahou, Ebrié, Potou, Aby and Tendo lagoons during the high dry season (March), the high rainy season (June), the low dry season (September) and the low rainy season (December)
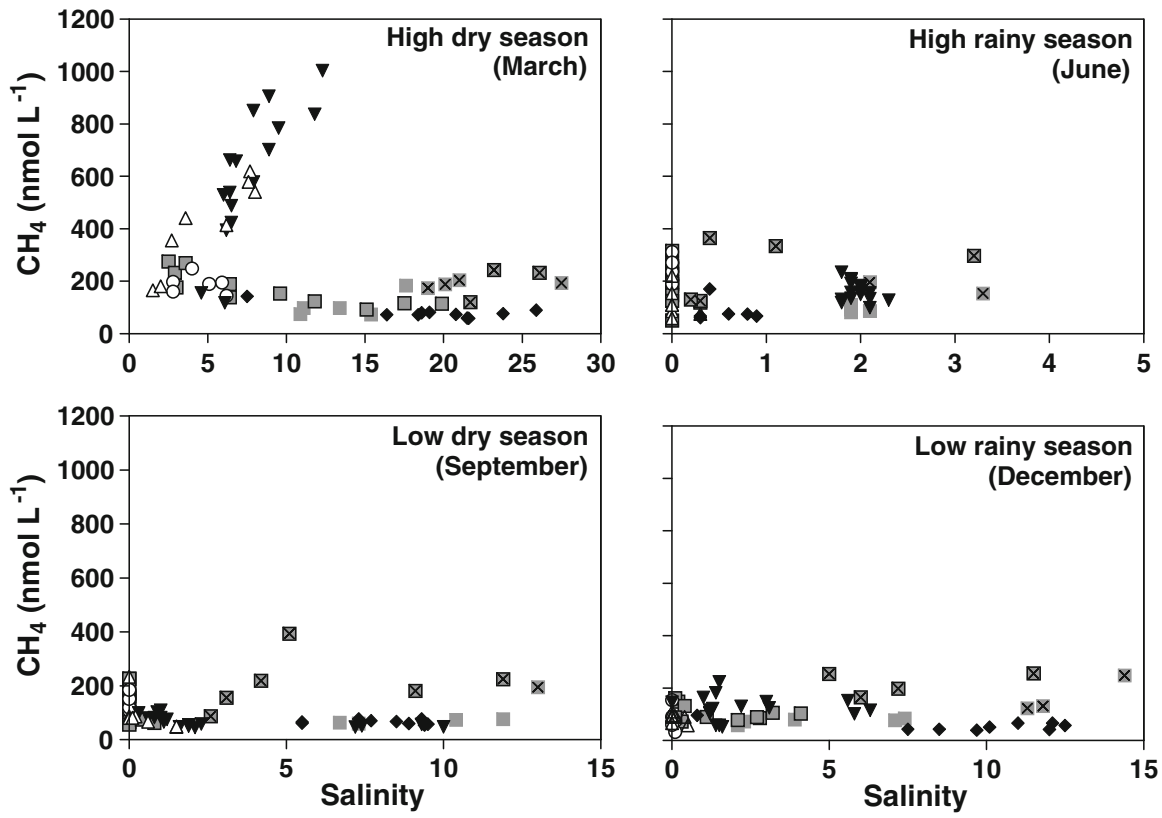

- Grand-Lahou $\square$ Western Ebrié $\square$ Eastern Ebrié $x$ in the vicinity of Abidjano Potou $\nabla$ Aby $\Delta$ Tendo
1995). During the high dry season (March), the decrease of freshwater inputs to the Aby and Tendo lagoons leads to a shallower mixed layer $(\sim 3 \mathrm{~m})$ compared to the other seasons $(\sim 4-6 \mathrm{~m})$, and also to a lesser degree of stratification due to the decrease of the vertical salinity gradient (Chantraine 1980). This leads to higher surface $\mathrm{CH}_{4}$ concentrations since the diffusion of $\mathrm{CH}_{4}$ across the pycnocline is enhanced by the lesser stratification. Moreover, the increase of salinity during the high dry season (March) (Figs. 5, 6) might inhibit the activity of methanotrophic bacteria in surface waters (De Angelis and Scranton 1993). Further, the shallower aerobic mixed layer during the high dry season reduces the probability of $\mathrm{CH}_{4}$ oxidation compared to the other seasons when the mixed layer is deeper. Furthermore, in the stratified Aby and Tendo lagoons, primary production is enhanced during high dry season compared to the other seasons due to the shallower mixed layer (enhanced light availability for a similar photic depth) and to a higher flux of inorganic nutrients from bottom waters across the pycnocline owing to lower stratification. Indeed, measurements of primary production reported by Chantraine (1980) were higher during the high dry season in the Aby (9.0 $\mathrm{g} \mathrm{O}_{2} \mathrm{~m}^{-2}$ day $^{-1}$ in February 1979) and Tendo lagoons (5.4 $\mathrm{g} \mathrm{O}_{2} \mathrm{~m}^{-2}$ day $^{-1}$ in February 1979) than the other seasons $\left(5.4 \mathrm{~g} \mathrm{O}_{2} \mathrm{~m}^{-2}\right.$ day $^{-1}$ in July 1979 and $3.1 \mathrm{~g} \mathrm{O}_{2} \mathrm{~m}^{-2}$ day ${ }^{-1}$ in October 1979 in the Aby lagoon; $3.1 \mathrm{~g} \mathrm{O}_{2} \mathrm{~m}^{-2}$ day $^{-1}$ in July 1979 and $2.2 \mathrm{~g} \mathrm{O}_{2} \mathrm{~m}^{-2}$ day $^{-1}$ in October 1979 in the Tendo lagoon). The seasonal patterns of $\mathrm{pCO}_{2}$, inorganic nutrients and chlorophyll- $a$ obtained during our cruises were consistent with an enhancement of primary production during the high dry season (Koné et al. 2009). In stratified marine and brackish systems, $\mathrm{CH}_{4}$ originates in majority from the decomposition of organic matter of phytoplankton origin, as for instance in Mariager fjord (Fenchel et al. 1995). Part of the $\mathrm{CH}_{4}$ produced from organic carbon exported from the surface to the anoxic bottom waters is oxidized mostly aerobically just above the pycnocline. The part of $\mathrm{CH}_{4}$ that escapes oxidation can be released to the atmosphere. Higher $\mathrm{CH}_{4}$ concentrations in surface waters of the Aby and Tendo lagoons reveal that $\mathrm{CH}_{4}$ production exceeded oxidation in theses two stratified lagoons, in contrast with the well-mixed Grand-Lahou and Potou lagoons.

Diffusive air-water $\mathrm{CH}_{4}$ fluxes in the rivers and lagoons

Table 3 shows the seasonal and annually integrated averages of $\mathrm{CH}_{4}, \% \mathrm{CH}_{4}, \mathrm{FCH}_{4}, k_{600}$ and $u$ in the 

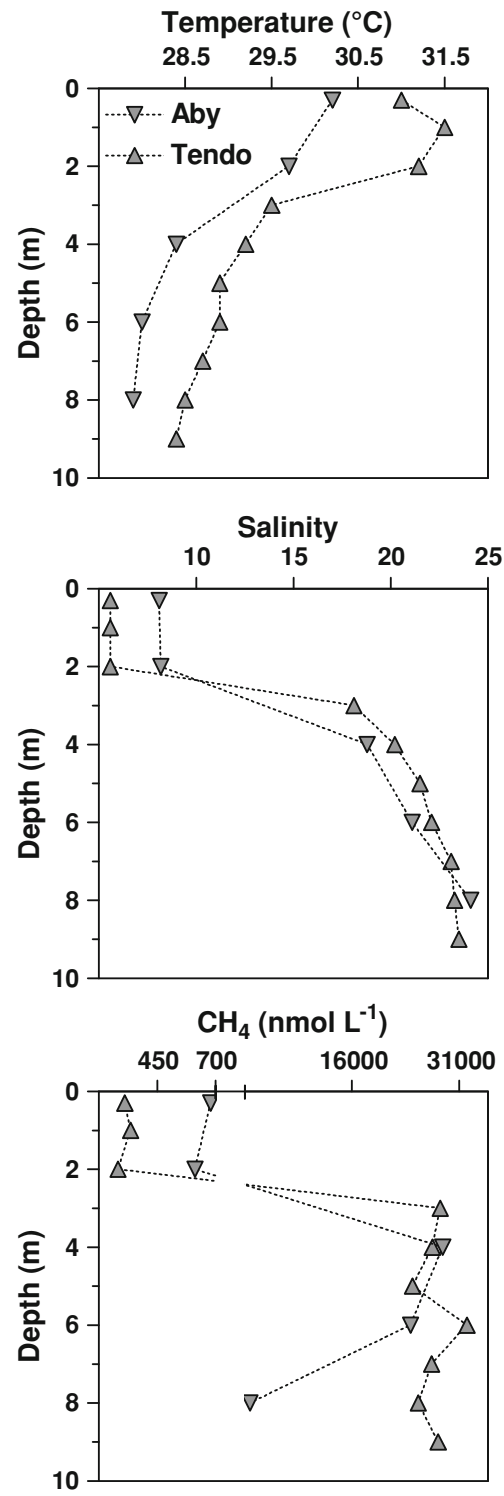

Fig. 6 Vertical profiles of salinity, water temperature $\left({ }^{\circ} \mathrm{C}\right)$ and $\mathrm{CH}_{4}$ concentration $\left(\mathrm{nmol} 1^{-1}\right)$ in the $\mathrm{Aby}\left(-3.231^{\circ} \mathrm{E} 5.228^{\circ} \mathrm{N}\right)$ and Tendo $\left(-3.110^{\circ} \mathrm{E} 5.142^{\circ} \mathrm{N}\right)$ lagoons during the high dry season (March)

sampled rivers and lagoons. The computed $k_{600}$ values were higher in the Comoé river than in the two other rivers due to stronger wind speeds related to a lesser wind damping effect by surrounding forests in the wider Comoé river. The monthly averages of $k_{600}$ values in the three rivers ranged between $2.2 \pm 0.2$ and $5.3 \pm 1.7 \mathrm{~cm} \mathrm{~h}^{-1}$ and bracket the average $k_{600}$ value of $3.3 \mathrm{~cm} \mathrm{~h}^{-1}$ assumed characteristic of large rivers by Cole and Caraco (2001). The computed monthly $k_{600}$ values in the lagoons ranged between $3.6 \pm 0.8$ and $9.0 \pm 4.0 \mathrm{~cm} \mathrm{~h}^{-1}$ and were higher than in the rivers owing to stronger wind speeds. The computed monthly $k_{600}$ values were higher in the Ebrié lagoons than in the other lagoons due to higher wind speeds. The seasonal variability of $k_{600}$ in estuaries has been seldom investigated. In the Scheldt estuary, monthly $k_{600}$ values range between 12.0 and $24.0 \mathrm{~cm} \mathrm{~h}^{-1}$ (Borges et al. 2004a). The higher $k_{600}$ values in the Scheldt estuary than in the Ivory Coast lagoons are related to higher wind speeds ranging seasonally from 2.6 to $7.5 \mathrm{~m} \mathrm{~s}^{-1}$ but also to a strong contribution of tidal currents to $k$ values. The Scheldt estuary is a strongly macro-tidal estuary with tidal amplitudes up to $5 \mathrm{~m}$ and tidal currents up to $1.5 \mathrm{~m} \mathrm{~s}^{-1}$. The restricted lagoons in Ivory Coast are micro-tidal such as the Ebrié lagoon where maximal tidal amplitude is lower than $0.6 \mathrm{~m}$, and where in most parts tidal currents are below $0.1 \mathrm{~m} \mathrm{~s}^{-1}$ with maximal tidal currents of $0.9 \mathrm{~m} \mathrm{~s}^{-1}$ in the Vridi channel (Brenon et al. 2004). Based on the relationship of O'Connor and Dobbins (1958), the upper most value of the contribution of tidal currents to $k_{600}$ can be evaluated to $4.2 \mathrm{~cm} \mathrm{~h}^{-1}$ using the maximal tidal current $0.9 \mathrm{~m} \mathrm{~s}^{-1}$ and a depth of $15 \mathrm{~m}$ at the Vridi channel. However, in most of the Ebrié lagoon tidal currents are low $\left(0.1 \mathrm{~m} \mathrm{~s}^{-1}\right)$ leading to a low contribution of tidal currents to $k_{600}$ evaluated with the O'Connor and Dobbins (1958) relationship ranging from 1.4 to $2.4 \mathrm{~cm} \mathrm{~h}^{-1}$, for depths ranging between 15 and $5 \mathrm{~m}$, respectively. While information is not available on tidal currents of other lagoons, they are expected to be similar than in the Ebrié lagoon for other restricted lagoons (Grand-Lahou) and lower in the chocked lagoons (Aby and Tendo).

The Bia, Tanoé and Comoé rivers were always sources of $\mathrm{CH}_{4}$ to the atmosphere and the diffusive air-water $\mathrm{CH}_{4}$ flux values ranged seasonally from 25 to $1187 \mu \mathrm{mol} \mathrm{m}{ }^{-2}$ day $^{-1}$, and annual integrated values ranged from 155 to $288 \mu \mathrm{mol} \mathrm{m}^{-2}$ day $^{-1}$. These values are within but in the lower end of the range of diffusive air-water $\mathrm{CH}_{4}$ fluxes from temperate rivers $\left(0-21562 \mu \mathrm{mol} \mathrm{m}{ }^{-2} \mathrm{day}^{-1}\right.$ ) (De Angelis and Scranton 1993; Lilley et al. 1996; Jones and Mulholland 1998a, b; Hope et al. 2001; Abril and Iversen 2002). The emission of $\mathrm{CH}_{4}$ from the three studied rivers was distinctly lower than the emission of $\mathrm{CH}_{4}$ from the Amazon River (ranging from 4625 to $12562 \mu \mathrm{mol} \mathrm{m}{ }^{-2}$ day $^{-1}$, Bartlett et al. 1990). This 
difference is due to the strong in-situ production of $\mathrm{CH}_{4}$ in the floodplains of Amazon, while the dynamics of $\mathrm{CH}_{4}$ in our three rivers seem to be mainly related to inputs from soil $\mathrm{CH}_{4}$ and dilution ("Dynamics of $\mathrm{CH}_{4}$ in the three rivers").

The five lagoons were always a source of $\mathrm{CH}_{4}$ to the atmosphere with diffusive air-water $\mathrm{CH}_{4}$ fluxes ranging seasonally from 20 to $2403 \mu \mathrm{mol} \mathrm{m}{ }^{-2}$ day $^{-1}$, the annual integrated values ranging from 78 to $338 \mu \mathrm{mol} \mathrm{m}{ }^{-2}$ day $^{-1}$, and an annual integrated area average for the five lagoons of $367 \pm 163 \mu \mathrm{mol} \mathrm{m} \mathrm{m}^{-2}$ $\mathrm{day}^{-1}$. These values are within but in the higher end of the range of diffusive air-water $\mathrm{CH}_{4}$ fluxes from tropical and temperate estuaries ranging from $\sim 20$ to $500 \mu \mathrm{mol} \mathrm{m}{ }^{-2}$ day $^{-1}$ (Bange et al. 1994; UpstillGoddard et al. 2000; Middelburg et al. 2002; Abril and Borges 2004; Bange 2006; Shalini et al. 2006).

Figure 7 compares the annual averages of $\% \mathrm{CH}_{4}$ and the annual averages of the air-gradient of $\mathrm{pCO}_{2}$ $\left(\Delta \mathrm{pCO}_{2}\right)$ in the three rivers and five lagoons. The three rivers were over-saturated in $\mathrm{CO}_{2}$ with respect to the atmosphere, and $\% \mathrm{CH}_{4}$ was positively correlated to $\Delta \mathrm{pCO}_{2}$. As discussed by Koné et al. (2009), $\mathrm{CO}_{2}$ dynamics in the three rivers seemed to be mainly related to inputs of soil $\mathrm{CO}_{2}$ and dilution during the flooding period, hence, the same processes that seemed to control $\mathrm{CH}_{4}$ dynamics in these rivers

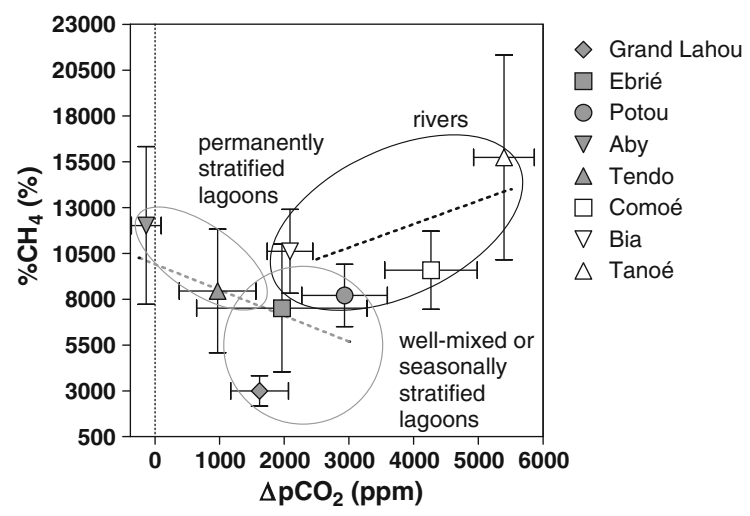

Fig. 7 Annual averages of the $\mathrm{CH}_{4}$ percent of saturation $\left(\% \mathrm{CH}_{4}\right.$ in $\left.\%\right)$ versus annual averages of the air-water gradient of $\mathrm{pCO}_{2}\left(\Delta \mathrm{pCO}_{2}\right.$ in $\left.\mathrm{ppm}\right)$ in the in the Grand-Lahou, Ebrié, Potou, Aby and Tendo lagoons, and in the Comoé, Bia and Tanoé rivers. The $\Delta \mathrm{pCO}_{2}$ data were obtained at the same locations and same time as the $\mathrm{CH}_{4}$ data (Koné et al. 2009). Linear regression for rivers (black dotted line) yields $r^{2}=0.42$ and $P=0.549$ and for lagoons (grey dotted line) yields $r^{2}=0.25$ and $P=0.393$. Error bars correspond to standard deviation on the mean
("Dynamics of $\mathrm{CH}_{4}$ in the three rivers"; Fig. 3). In the five lagoons, $\% \mathrm{CH}_{4}$ was negatively correlated to $\Delta \mathrm{pCO}_{2}$, and the Aby lagoon that was the most oversaturated in $\mathrm{CH}_{4}$ was under-saturated in $\mathrm{CO}_{2}$, unlike the other four lagoons that were over-saturated in $\mathrm{CO}_{2}$. The permanent stratification of the Aby and Tendo lagoons, enhances primary production and organic carbon export across the pycnocline leading to a low $\mathrm{CO}_{2}$ over-saturation (Tendo lagoon) or a $\mathrm{CO}_{2}$ under-saturation (Aby lagoon), but at the same time this promotes anoxia in bottom waters that enhance methanogenesis and leads to stronger $\mathrm{CH}_{4}$ over-saturation than the other lagoons that are not permanently stratified.

\section{Conclusions}

Whatever the season, surface waters were oversaturated in $\mathrm{CH}_{4}$ with respect to atmospheric equilibrium in the three studied rivers (2221-38719\%) and the five studied lagoons (1496-51843\%). The diffusive air-water $\mathrm{CH}_{4}$ fluxes were consequently always directed to the atmosphere, ranging between 25 and $1187 \mu \mathrm{mol} \mathrm{m}{ }^{-2}$ day $^{-1}$ in the rivers and between 20 and $2403 \mu \mathrm{mol} \mathrm{m}{ }^{-2}$ day $^{-1}$ in the lagoons. The emission of $\mathrm{CH}_{4}$ from the rivers and lagoons we report should be considered as minimal estimates for several reasons. The diffusive air-water $\mathrm{CH}_{4}$ fluxes were computed with the Raymond and Cole (2001) $k$ parameterization based on a compilation of tracer measurements in rivers and estuaries that most probably provides conservative $k$ values. In rivers and estuarine environments, water currents strongly enhance water turbulence and $k$ (Zappa et al. 2003, 2007; Borges et al. 2004a, b), although it is probable that this not adequately quantified in $k$ values derived from tracer methods that have a characteristic time scale ( $\sim 1$ day) that is incompatible with the water current characteristic time scale ( $\sim 1$ min). We did not quantify ebullition $\mathrm{CH}_{4}$ fluxes, which in macrotidal estuarine systems can represent $\sim 50 \%$ or more of the total emission of $\mathrm{CH}_{4}$ to the atmosphere (Chanton et al. 1989; Kelley et al. 1990; Shalini et al. 2006). Finally, direct emission of $\mathrm{CH}_{4}$ from intertidal sediments to the atmosphere strongly contribute in estuarine environments to the overall $\mathrm{CH}_{4}$ emission at ecosystem scale ranging from $\sim 7000 \mu \mathrm{mol} \mathrm{m}{ }^{-2} \mathrm{day}^{-1}$ in oligohaline regions to 
$\sim 30 \mu \mathrm{mol} \mathrm{m}{ }^{-2}$ day $^{-1}$ in polyhaline regions (refer to review by Abril and Borges 2004).

Acknowledgements The authors are indebted to Prof. A. Ouattara and Prof. G. Gourène from the Laboratoire d'Environnement et de Biologie Aquatique of the University of Abobo-Adjamé for assistance and support throughout the project and field work, N.M. Seu for help in sampling, D. Poirier for $\mathrm{CH}_{4}$ analysis, and T. Christensen (Associate Editor) and an anonymous reviewer for comments on a previous version of the manuscript. A.V.B. and B.D. are research associates at the Fonds National de la Recherche Scientifique. Y.J.-M.K. received financial support from the Ivory Coast government, from the Agence Universitaire de la Francophonie (6313PS657) and the Fondation Alice Seghers. This is MARE contribution $n^{\circ} 167$.

\section{References}

Abril G, Borges AV (2004) Carbon dioxide and methane emissions from estuaries. In: Tremblay A, Varfalvy L, Roehm C, Garneau M (eds) Greenhouse gases emissions from natural environments and hydroelectric reservoirs: fluxes and processes. Springer, Berlin

Abril G, Iversen N (2002) Methane dynamics in a shallow, non-tidal, estuary (Randers Fjord, Denmark). Mar Ecol Prog Ser 230:171-181. doi:10.3354/meps230171

Abril G, Commarieu M-V, Guérin F (2007) Enhanced methane oxidation in an estuarine turbidity maximum. Limnol Oceanogr 52:470-475

Adingra AA, Arfi R (1998) Organic and bacterial pollution in the Ebrié lagoon, Côte d'Ivoire. Mar Pollut Bull 36:689695. doi:10.1016/S0025-326X(98)00033-2

Bange HW (2006) Nitrous oxide and methane in European coastal waters. Estuar Coast Shelf Sci 70:361-374. doi: 10.1016/j.ecss.2006.05.042

Bange HW, Bartell UH, Rapsomanikis S, Andreae MO (1994) Methane in the Baltic and North Seas and a reassessment of the marine emissions of methane. Global Biogeochem Cycles 8:465-480. doi:10.1029/94GB02181

Barnes RSK (1980) Coastal lagoons. Cambridge University Press, Cambridge

Bartlett KB, Bartlett DS, Harris RC, Sebacher DI (1987) Methane emissions along a salt marsh salinity gradient. Biogeochemistry 4:183-202. doi:10.1007/BF02187365

Bartlett KB, Crill PM, Bonassi JA, Richey JE, Harris RC (1990) Methane flux from the Amazon River floodplain: emissions during rising water. J Geophys Res 95:1677316778. doi:10.1029/JD095iD10p16773

Bastviken D, Cole J, Pace M, Tranvik L (2004) Methane emissions from lakes: dependence of lake characteristics, two regional assessments, and a global estimate. Global Biogeochem Cycles 18:GB4009. doi:10.1029/2004GB002238

Binet D, Le Reste L, Diouf PS (1995) The influence of runoff and fluvial outflow on the ecosystems and living resources of West African coastal waters. FAO Fish Tech Pap 349:89-118

Borges AV, Vanderborght J-P, Schiettecatte L-S, Gazeau F, Ferrón-Smith S, Delille B, Frankignoulle M (2004a)
Variability of the gas transfer velocity of $\mathrm{CO}_{2}$ in a macrotidal estuary (The Scheldt). Estuaries 27:595-605. doi: 10.1007/BF02907647

Borges AV, Delille B, Schiettecatte L-S, Gazeau F, Abril G, Frankignoulle $\mathrm{M}$ (2004b) Gas transfer velocities of $\mathrm{CO}_{2}$ in three European estuaries (Randers Fjord, Scheldt, and Thames). Limnol Oceanogr 49:1630-1641

Brenon I, Monde S, Pouvreau N, Maurin JC (2004) Modeling hydrodynamics in the Ebrié Lagoon (Côte d'Ivoire). J Afr Earth Sci 39:535-540. doi:10.1007/s10661-008-0649-z

Castel J, Caumette P, Herbert R (1996) Eutrophication gradients in coastal lagoons as exemplified by the Bassin d'Arcachon and the étang du Prévost. Hydrobiologia 329:ix-xxviii. doi:10.1007/BF00034542

Chanton JP, Martens CS, Kelley CA (1989) Gas transport from methane-saturated, tidal freshwater and wetland sediments. Limnol Oceanogr 34:807-819

Chantraine J-M (1980) La lagune Aby (Côte d'Ivoire). Morphologie, hydrologie, paramètres physico-chimiques. Doc Sci Centre Rech Océanogr Abidjan 2:39-70

Cicerone RJ, Oremland RS (1988) Biogeochemical aspects of atmospheric methane. Global Biogeochem Cycles 2:299327. doi:10.1029/GB002i004p00299

Cole JJ, Caraco NF (2001) Carbon in catchments: connecting terrestrial carbon losses with aquatic metabolism. Mar Freshw Res 52:101-110. doi:10.1071/MF00084

De Angelis MA, Lilley MD (1987) Methane in surface waters of Oregon estuaries and rivers. Limnol Oceanogr 32: $716-722$

De Angelis MA, Scranton MI (1993) Fate of methane in the Hudson river and estuary. Global Biogeochem Cycles 7:509-523. doi:10.1029/93GB01636

Denman KL, Brasseur G, Chidthaisong A, Ciais P, Cox PM, Dickinson RE, Hauglustaine D, Heinze C, Holland E, Jacob D, Lohmann U, Ramachandran S, da Silva Dias PL, Wofsy SC, Zhang X (2007) Couplings between changes in the climate system and biogeochemistry. In: Solomon $S$, Qin D, Manning M, Chen Z, Marquis M, Averyt KB, Tignor M, Miller HL (eds) Climate change 2007: the physical science basis. Contribution of working group I to the fourth assessment report of the intergovernmental panel on climate change. Cambridge University Press, Cambridge

Diaz RJ, Rosenberg R (2008) Spreading dead zones and consequences for marine ecosystems. Science 321:926-929. doi:10.1126/science. 1156401

Durand JR, Chantraine JM (1982) L'environnement climatique des lagunes ivoiriennes. Rev Hydrobiol Trop 15:85-113

Durand JR, Skubich M (1982) Les lagunes ivoiriennes. Aquaculture 27:211-250. doi:10.1016/0044-8486(82)90059-X

Dürr HH, Meybeck M, Dürr SH (2005) Lithologic composition of the Earth's continental surfaces derived from a new digital map emphasizing riverine material transfer. Global Biogeochem Cycles 19:GB002515. doi:10.1029/2005GB002515

Fenchel T, Bernard C, Esteban G, Findlay BJ, Hansen PJ, Iversen N (1995) Microbial diversity and activity in a Danish fjord with anoxic deep waters. Ophelia 43:45-100

Forster P, Ramaswamy V, Artaxo P, Berntsen T, Betts R, Fahey DW, Haywood J, Lean J, Lowe DC, Myhre G, Nganga J, Prinn R, Raga G, Schulz M, Van Dorland R (2007) Changes in atmospheric constituents and in 
radiative forcing. In: Solomon S, Qin D, Manning M, Chen Z, Marquis M, Averyt KB, Tignor M, Miller HL (eds) Climate change 2007: The physical science basis. Contribution of working group I to the fourth assessment report of the intergovernmental panel on climate change. Cambridge University Press, Cambridge

Hirota M, Senga Y, Seike Y, Nohara S, Kunii H (2007) Fluxes of carbon dioxide, methane and nitrous oxide in two contrastive fringing zones of coastal lagoon, Lake Nakaumi, Japan. Chemosphere 68:597-603. doi:10.1016/ j.chemosphere.2007.01.002

Hope D, Palmer SM, Billett MF, Dawson JC (2001) Carbon dioxide and methane evasion from temperate peatland stream. Limnol Oceanogr 46:847-857

Houweling S, Dentener F, Lelieveld J (2000) Simulation of preindustrial atmospheric methane to constrain the global source strength of natural wetlands. J Geophys Res 105:17243-17255. doi:10.1029/2000JD900193

Hughes RH, Hughes JS (1992) A directory of African wetlands. IUCN, UNEP and WCMC, Gland, Nairobi, Cambridge

Jallow BP, Toure S, Barrow MMK, Mathieu AA (1999) Coastal zone of the Gambia and the Abidjan region in Côte d'Ivoire: sea level rise vulnerability, response strategies, and adaptation options. Clim Res 12:129-136. doi: $10.3354 / \mathrm{cr} 012129$

Johnson HK (1999) Simple expressions for correcting wind speed data for elevation. Coast Eng 36:263-269. doi: 10.1016/S0378-3839(99)00016-2

Jones JB, Mulholland PJ (1998a) Influence of drainage basin topography and elevation on carbon dioxide and methane supersaturation of stream water. Biogeochemistry 40:5772. doi:10.1023/A:1005914121280

Jones JB, Mulholland PJ (1998b) Methane input and evasion in a hardwood forest stream: effects of subsurface flow from shallow and deep pathways. Limnol Oceanogr 43:1243-1250

Kelley CA, Martens CS, Chanton JP (1990) Variations in sedimentary carbon remineralization rates in the White Oak River estuary, North Carolina. Limnol Oceanogr 35:372-383

Kelley CA, Martens CS, Ussler W III (1995) Methane dynamics across a tidally flooded riverbank margin. Limnol Oceanogr 40:1112-1129

Khalil MAK, Butenhoff CL, Rasmussen RA (2007) Atmospheric methane: trends and cycles of sources and sinks. Environ Sci Technol 41:2131-2137. doi:10.1021/es061791t

Kjerfve B (1985) Comparative oceanography of coastal lagoons. In: Wolfe DA (ed) Estuarine variability. Academic Press, New York

Koné YJM, Abril G, Kouadio KN, Delille B, Borges AV (2009) Seasonal variability of carbon dioxide in the rivers and lagoons of Ivory Coast (West Africa). Estuar Coast 32:246-260. doi:10.1007/s12237-008-9121-0

Kouassi AM, Kaba N, Métongo BS (1995) Land-based sources of pollution and environmental quality of the Ebrié lagoon waters. Mar Pollut Bull 30:295-300. doi:10.1016/0025326X(94)00245-5

Lilley MD, De Angelis MA, Olson EJ (1996) Methane concentrations and estimated fluxes from Pacific northwest rivers. Mitt Int Ver Limnol 25:187-196

Middelburg JJ, Nieuwenhuize J, Iversen N, Høgh N, de Wilde H, Helder W, Seifert R, Christof O (2002) Methane distribution in tidal estuaries. Biogeochemistry 59:95119. doi:10.1023/A:1015515130419

Mikaloff Fletcher SE, Tans PP, Bruhwiler LM, Miller JB, Heimann M (2004) $\mathrm{CH}_{4}$ sources estimated from atmospheric observations of $\mathrm{CH}_{4}$ and its ${ }^{13} \mathrm{C} /{ }^{12} \mathrm{C}$ isotopic ratios: 1. Inverse modeling of source processes. Global Biogeochem Cycles 18:GB4004. doi:10.1029/2004GB002223

O'Connor DJ, Dobbins WE (1958) Mechanism of reaeration in natural streams. Trans Am Soc Civ Eng 123:641-684

Purvaya R, Ramesh R (2000) Human impacts on methane emission from mangrove ecosystems in India. Reg Environ Change 1:86-97. doi:10.1007/PL00011537

Raymond PA, Cole JJ (2001) Gas exchange in rivers and estuaries: choosing a gas transfer velocity. Estuaries 24:312-317. doi:10.2307/1352954

Richey JE, Devol AH, Wofsy SC, Victoria R, Riberio MNG (1988) Biogenic gases and the oxidation and reduction of carbon in Amazon River and floodplain waters. Limnol Oceanogr 33:551-561

Richey JE, Melack JM, Aufdemkampe AK, Ballester VM, Hess LL (2002) Outgassing from Amazonian rivers and wetlands as a large tropical source of atmospheric $\mathrm{CO}_{2}$. Nature 416:617-620. doi:10.1038/416617a

Rigby M, Prinn RG, Fraser PJ, Simmonds PG, Langenfelds RL, Huang J, Cunnold DM, Steele LP, Krummel PB, Weiss RF, O'Doherty S, Salameh PK, Wang HJ, Harth CM, Mühle J, Porter LW (2008) Renewed growth of atmospheric methane. Geophys Res Lett 35:L22805. doi: 10.1029/2008GL036037

Sansone FJ, Holmes ME, Popp BN (1999) Methane stable isotopic ratios and concentrations as indicators of methane dynamics in estuaries. Global Biogeochem Cycles 13:463-474. doi:10.1029/1999GB900012

Scheren PAGM, Kroeze C, Janssen FJJG, Hordijk L, Ptasinski KJ (2004) Integrated water pollution assessment of the Ebrié lagoon, Ivory Coast, West Africa. J Mar Syst 44:117. doi:10.1016/j.jmarsys.2003.08.002

Scranton MI, McShane K (1991) Methane fluxes in the southern North Sea: the role of European rivers. Cont Shelf Res 11:37-52. doi:10.1016/0278-4343(91)90033-3

Shalini A, Ramesh R, Purvaja R, Barnes J (2006) Spatial and temporal distribution of methane in an extensive shallow estuary, south India. J Earth Syst Sci 115:451-460. doi: 10.1007/BF02702873

Smith LK, Lewis WM Jr, Chanton JP, Cronin G, Hamilton SK (2000) Methane emissions from the Orinoco River floodplain, Venezuela. Biogeochemistry 51:113-140. doi: 10.1023/A:1006443429909

Sorokin YI, Sorokin P, Giovanardi O, Dalla Venezia L (1996) Study of ecosystem of the Lagoon of Venice, with emphasis on anthropogenic impact. Mar Ecol Progr Ser 141:247-261. doi:10.3354/meps 141247

St Louis V, Kelly C, Duchemin E, Rudd JWM, Rosenberg DM (2000) Reservoir surface as sources of greenhouse gases to the atmosphere: a global estimate. Bioscience 20:766-775. doi:10.1641/0006-3568(2000)050[0766:RSASOG]2.0.CO;2

Upstill-Goddard RC, Barnes J, Frost T, Punshon S, Owens NJP (2000) Methane in the Southern North Sea: low salinity inputs, estuarine removal and atmospheric flux. Global Biogeochem Cycles 14:1205-1217. doi:10.1029/1999GB001236 
Verma A, Subramanian V, Ramesh R (2002) Methane emission from a coastal lagoon: Vembanad Lake, West Coast India. Chemosphere 47:883-889. doi:10.1016/S0045-6535(01) 00288-0

Wanninkhof R (1992) Relationship between wind speed and gas exchange over the ocean. J Geophys Res 97:73737382. doi: $10.1029 / 92 J C 00188$

Ward BB, Kilpatrick KA, Novelli PC, Scranton MI (1987) Methane oxidation and methane fluxes in the ocean surface layer and deep anoxic waters. Nature 327:226-229. doi:10.1038/327226a0

Wilkinson PE, Lamontagne RE, Larson RE, Swinnerton JW (1978) Atmospheric trace gases and land and sea breezes at the Sepik River Coast of Papua, New Guinea. J Geophys Res 83:3672-3674

Wuebbles DJ, Hayhoe K (2002) Atmospheric methane and global change. Earth Sci Rev 57:177-210. doi:10.1016/ S0012-8252(01)00062-9
Yamamoto S, Alcauskas JB, Crozier TE (1976) Solubility of methane in distilled water and seawater. J Chem Eng Data 21:78-80. doi:10.1021/je60068a029

Zappa CJ, Raymond PA, Terray EA, McGillis WR (2003) Variation in surface turbulence and the gas transfer velocity over a tidal cycle in a macro-tidal estuary. Estuaries 26:1401-1415. doi:10.1007/BF02803649

Zappa CJ, McGillis WR, Raymond PA, Edson JB, Hintsa EJ, Zemmelink HJ, Dacey JWH, Ho DT (2007) Environmental turbulent mixing controls on air-water gas exchange in marine and aquatic systems. Geophys Res Lett 34:L10601. doi:10.1029/2006GL028790

Zhang GL, Zhang J, Kang YB, Liu SM (2004) Distributions and fluxes of methane in the East China Sea and the Yellow Sea in spring. J Geophys Res 109:C07011. doi: 10.1029/2004JC002268 